\title{
Urban Improvisations: The Profanatory Tactics of Spectacularized Spaces
}

\section{Paola Berenstein Jacques}

\section{Translated by Micaela Kramer}

My focus in this paper is not on the possibility of criticism of the urban contemporary spectacularization process, but on its opposite; that is, on the improvisations, the vitality and the intensity of public life within more demotic or informal areas of the city. According to Mílton Santos, these are opaque urban zones, "spaces of closeness and creativity, contrary to the luminous zones and spaces of exactitude" (Santos 261). Such spaces gain visibility through negation, precisely because of their exclusion from the spotlights of the vaster process of contemporary urban spectacularization (Jacques Espectacularizacao). This process of exclusion is one of the leading factors both for the current impoverishment of bodily experiences in public spaces, and for the disavowal of conflicts and dissension in these spaces (especially for the attempts to hide, reduce, or eliminate the demotic vitality of these opaque city spaces). According to the logic of the spectacle, these spaces should be duly ordered, sterilized and gentrified by urban projects of "revitalization," so that they too become luminous, mediatized and spectacularized spaces.

These so-called revitalization projects-this designation insinuates that the spaces to be "revitalized" are dead, lacking in life, or that the kind of existent life is not appropriate and must be replaced-are almost always pacification and spectacularization projects. Falling within the same spectacularizing logic, based on the creation of images and the construction of urban consensus, contemporary public spaces and cultures are seen as strategic for the construction and promotion of the consensual images of cities. In other words, they are thought of as publicity pieces for immediate consumption. Current contemporary urban projects are developed throughout the world according to the same homogenizing, spectacular, and consensual strategy. These projects seek to transform public spaces into stage sets, disembodied spaces, facades without bodies: pure publicity images. Contemporary scenographic cities are increasingly standardized and uniform; they are pacified spaces, apparently destitute of inherent conflicts, of discord and misunderstandings; in short, they are apolitical spaces.

A clue of micro-resistance towards the process of urban spectacularization can be found in the everyday use of the city, in particular, in non-planned or in deviating experiences of public spaces; that is, in the quotidian conflictive and non-consensual uses of the city that oppose planned ways of use. If we think of separation, as Guy Debord writes, as "the alpha and the omega of the spectacle" (Debord 27), and if we think of the spectacle and consumption-which today have the museum and tourism as their greatest example (Agamben Profanations) -as the two sides of the same impossibility of using, experiencing, and inhabiting, we can think of use as a form of critical resistance. If the process of urban spectacularization not only pacifies but also sacralizes public spaces, which thereby become luminous, we can also think of Agamben's notion of profanation (2007) as a way of problematizing the contemporary urban question, especially the question of sacralized public spaces. ${ }^{1}$

To profane luminous public spaces would imply removing them from the sphere of the sacred, as well as from the space of consumption and spectacular exhibition, and restituting them to the common use of inhabitants, passers-by, or other users. Agamben states that "if to consecrate (sacrare) was the term that indicated the removal of things from the sphere of human law, 'to profane' meant, conversely, to return them to the free use of men." He cites the jurist Trebatius to explain that "[i]n the strict sense profane is the term for something that was once sacred or religious and is returned to the use and property of men" (73). This passage from the sacred to the profane, of returning the spaces confiscated by the spectacle to common use, can also be obtained by the notion of play, ${ }^{2}$ which would be an incongruent form of use of the sacred. This means that play, together with parties and dances, can serve as instruments of profanation. Again, according to Agamben, "[t]o return to play its purely profane vocation is a political task" (77).

Already in the 1950s, the Situationists, led by Debord, proposed urban games as anti-spectacular tactics-in particular, psychogeographic games and drifting. These are, in effect, good examples of profanatory tactics. In the text "Contribution to a Situationist Definition of Play," they make it clear that "[t]he new phase of affirmation of play seems to be characterized by the disappearance of any element of competition. The element of competition must disappear in favor of a more authentically collective concept of play: the common creation of selected ludic ambiances" (Jacques Apologia 60). ${ }^{3}$ It is precisely this competitive nature that transforms certain games, such as sports, into mediatic spectacles. Yet, if profanatory urban tactics can be provoked, created or constructed, as the Situationists have done, might they not be simply survival tactics, or of daily and banal use, which deviate from the planned uses for urban spaces?

In The Practice of Everyday Life, Michel de Certeau proposes the idea of deviational tactics. These are tactics that do not obey the law of the place, and are not defined by it. The author counters these with technocratic strategies:

"[w]hat distinguishes them at the same time concerns the types of operations and the role of spaces: strategies are 
able to produce, tabulate, and impose these spaces, when these operations take place, whereas tactics can only use, manipulate, and divert these spaces" (De Certeau 30). ${ }^{4}$ De Certeau studies the different forms of utilization and consumption that are present in daily use and actions, especially in their guilefulness, which would be the almost invisible, creative ways of using or deviating from what has been imposed on each occasion. These are "stubborn, guileful, everyday practices," discrete yet essential inversions that subvert from within: a form of revenge of the tactics of deviational usage, which are oftentimes called the "vulgarization" of culture or the degradation of the city. De Certeau cites Von Büllow in order to explain that the tactic is movement "within the enemy's field of vision...and within enemy territory." "It operates in isolated action, blow by blow. It takes advantage 'of opportunities' and depends on them... It must vigilantly make use of the cracks that particular conjunctions open in the surveillance of the proprietary powers. It poaches in them. It creates surprises in them. It can be where it is less expected. It is a guileful ruse" (37).

De Certeau's notion of guile is very similar to what we can find in the everyday life of inhabitants of the more opaque zones of cities, in particular in those worldwide peripheries, as, for instance, in the tactics used by informal constructers of Brazilian favelas, who, each day, create, modify, and transform other uses and possibilities of appropriation by the very practitioners-what I have previously designated as "space in movement" (Jacques Estética 149). The space in movement is not simply connected to physical space; it is especially linked to the movement of the trajectory, to the experience of traversing it, and it is directly linked to its actors, who are as much those who traverse these opaque spaces in everyday life as those who continuously build and transform them. The opaque zones of peripheral cities, or of the peripheries of large globalized cities, are spaces in constant movement precisely because their users/inhabitants are truly responsible for its collective construction. Such tactics or guileful behavior are not restricted to the city's more circumscribed opaque spaces, such as the favelas, but also infiltrate its more luminous spaces through a number of actors: street vendors, homeless people, scavengers, prostitutes, etc. These are the ones who, not fortuitously, are the first targets of an asepsis promoted by the majority of urban pacification projectsso-called "revitalization." We might think of these divergence tactics, guileful behaviors, or opaque uses of space as profanatory tactics, especially when they occur in public spaces of the luminous, sacralized, and spectacular zones, and when they are directly related to a bodily experience of the cities.

The more extensive process of spectacularization is directly related as much to the current security-based, homogenizing, and consensual pacification of public spaces as to the impoverishment of the bodily experience of cities when it comes to everyday ordinary practice. This makes me rethink the question of the everyday body in urban space, as Milton Santos would say, and of the corporeality of slow men, whose bodies are materially sensitive certainties. These are men "for whom images are mirages, and who can not be attuned for too long with this perverse imaginary, and end up discovering its fabulations" (Santos Natureza 261). De Certeau called these slow men who still walk through the streets the ordinary practitioners of the city: "The ordinary practitioners of the city live down below, below the thresholds at which visibility begins. They walk-an elementary form of this experience of the city; they are walkers, Wandersmanner, whose bodies follow the thicks and thins of an urban 'text' they write without being able to read it. These practitioners make use of spaces that cannot be seen; their knowledge of them is as blind as that of lovers in each other's arms" (De Certeau 93).

The ordinary practitioners of cities actualize urban projects, as well as urbanism itself, through the practice, usage, or everyday experience of urban spaces, thereby reinventing, subverting, or profaning them. Urban planners indicate possible uses for planned space, yet the ones who actualize them are those who experience the space in everyday life. What legitimates that which has been planned are the appropriations of spaces and improvised evasions from them. In other words, bodily experiences continually reinvent urban spaces in everyday life. What is significant in this process of reinvention are the overall uses, tactics and actions-the appropriations made a posteriori, with their deviations, bypaths, and guile. The ordinary practitioners of cities experience spaces while practicing them, and thereby endow them with another "body" through the simple practice of these spaces. I believe it is precisely such urban improvisations, with their profanatory tactics, that can help us to better interrogate and add vitality to our contemporary cities, thus indicating possibilities for a more embodied urbanism.

\section{Notes}

${ }^{1}$ Agamben himself suggests this when he cites the subject of the "Museum" as a topical site of this impossibility of use, caused by the separation from spectacle. He writes: "The museification of the world is today an accomplished fact. One by one, the spiritual potentialities that defined the people's lives-art, religion, philosophy, the idea of nature, even politics - have decisively withdrawn into the Museum. 'Museum' here is not a given physical space or place but the separate dimension to which what was once-but is no longer-felt as true and decisive has moved. In this sense, the Museum can coincide with an entire city (such as Evora and Venice, which were declared World Heritage sites), a region (when it is declared a park or nature preserve), and even a group of individuals (insofar as they represent a form of life that has disappeared)" (2007, 84). N.T.: Here, as with subsequent quoted passages from Profanations, I am citing the published translation by Jeff Fort. Zone Books, 2007. 
${ }^{2}$ In her provocation in the encounter CORPOCIDADE 2010, Silvana Olivieri (see notebook of provocations at http://www.corpocidade.dan.ufba.br/2010) proposes a kind of game-an "opadometer" (a reference to the Situationists, who had proposed an euphoriameter). This would be based on Georges Perec's idea of relating the everyday to opacity: "The problem isn't that of inventing space, even less of reinventing it, but of interrogating it, for what we call everyday isn't obvious; rather, it is opaque" (Perec in Espèces d'Espaces.)

${ }^{3}$ N.T.: I am citing from Reuben Keehan's translation of "Contribution to a Situationist Definition of Play." http://www.cddc.vt.edu/sionline/si/play.html

${ }^{4}$ N.T.: Here, and in subsequent passages, I am citing from Steven Rendall's translation of The Practice of Everyday Life, published by University of California Press, 1988.

\section{Works Cited}

Agamben, Giorgio. Profanations. Trans. Jeff Fort. New York: Zone Books, 2007. São Paulo: Boitempo, 2007. Print.

Britto, Fabiana Dultra and Paola Berenstein Jacques. "Cenografias e corpografias urbanas: Um diálogo sobre as relacões entre corpo e cidade." Paisagens do Corpo. Salvador: PPG-AU/FAUFBA, 2008. Print.

Debord, Guy. La société du spectacle. Paris: Gallimard, 1992. Print.

De Certeau, Michel. The Practice of Everyday Life. Trans. Steven Rendall. Berkeley: $U$ of California P, 1988. Print.

Guattari, Félix and Suely Rolnik. Micropolítica, cartografias do desejo. Petrópolis: Vozes, 1986. Print.

Jacques, Paola Berenstein, ed. Apologia da deriva, escritos situacionistas sobre a cidade. Rio de Janeiro: Casa da Palavra, 2003. Print.

Jacques, Paola Berenstein. Estética da ginga, a arquitetura das favelas através da obra de Hélio Oiticica. Rio de Janeiro: Casa da Palavra, 2001. Print.

Jacques, Paola Berenstein.“Espetacularização urbana contemporânea.” Territórios Urbanos e Políticas Culturais. Salvador: PPG-AU/FAUFBA, 2004. Print.

Perec, Georges. Espèces d'Espaces. Paris: Galilée, 2000. Print.

Santos, Mílton. A natureza do espaço, técnica e tempo, razão e emoção. São Paulo: Hucitec, 1996. Print. 